\title{
The Influence of Local Taboos and Beliefs on Social Practice of Fisheries Community in North Coast of Central Java to Develop Environment in Industrial Revolution 4.0
}

\author{
Nurhayati $^{1, *}$, Agus Subiyanto ${ }^{1}$, Astri Adriani Allien ${ }^{1}$ \\ ${ }^{1}$ Department of Linguistics, Faculty of Humanities, Diponegoro University, Semarang - Indonesia
}

\begin{abstract}
The wave of industrial revolution 4.0 influences almost all aspects of every life, covering the fishermen's activities. In order to survive in global competition, traditional fishermen must work hard, fast, smartly, and appropriately to increase production. However, the existence of taboos and local beliefs that has been considered as a device of maintaining environment may become obstacle of their activities. The study aims to identify the influence of the taboos and beliefs controlling the Fisheries Community in North Coast of Central Java on their daily activities to survive as well as to develop their environment. Data on the research are the narrative of the respondents regarding the taboos and beliefs they have listened. Data are gathered through deep interview of six respondents from three fishing areas, those are Demak, Kendal, and Semarang. Using critical discourse analysis approach, the researchers found that local taboos influence their perception that certain natural phenomena are controlled by spirits, so that some bad events happened to the community may be interpreted as consequences of violating the taboos. The beliefs construct by the governed by the unseen power rather than usual phenomena. This gives impact to the way they develop their environment.
\end{abstract}

Keywords: Local taboos and beliefs; fisheries community; local perception

\section{Introduction}

One of global problems in fishing industry in the industrial revolution era 4.0 is exploitation of fish stock because of increasing fish demand for both food and feed. Effort to fulfill the demand supported by technological advances may change the human behaviour from keeping the sea to destructing habitats, producing pollution, and exploiting the fish stock. Realizing the negative impact of the global wave, both government and non-government organizations have continuously campaigned the importance of balancing the marine ecosystem and fulfilling human life necessities.

Of the priority efforts, there is increasing fishery community awareness of keeping the sea clean and balancing the population of the marine habitat. Some studies showed that local tradition such as taboos, beliefs, and norms managed by informal institutions made significant contribution to sustaining balanced ecosystem [1-6].

Even though the research focusing on the importance of the local wisdom has been devoted to making marine conservation, few studies have been conducted to investigate the similar problems in the fishery community in The North Coast of Central Java. Generally, researchers paid more attention to the economic condition of the community [7], on the environment [8], and on sites [9]. It shows that a study that investigates the influence of the attitude fishery community regarding the taboos, beliefs, and norms, towards the marine habitat has not been explored yet. People do not know whether or not the community still believes such values. There is also no information about whether their attitude has a relationship with the condition of the existing habitat.

Based on the condition, the study purposes to investigate the existence of the taboos, beliefs, and norms, of the fishery community in the North Coast of Central Java, and the influence of the values on the effort to construct the balanced environment. Such information is necessary to make decision in order to keep the balanced condition of the marine habitat in Tambak Lorok site and to educate the community to preserve the ecosystem.

\section{Research Method}

The object of the research is the fishery community located in Semarang, Demak, and Kendal as a representation of the fishery community in The North Coast of Central Java. Six informants from the three areas were chosen randomly to be interviewed. The demographic information of the six informants is reported in Table 1.

* Corresponding author: noerhytwid@yahoo.com 
Table 1. Demographic Information of Informants

\begin{tabular}{|l|l|l|l|}
\hline No & Name of informant & age & Residence \\
\hline 1. & Nasikin & 47 & Demak \\
\hline 2. & Suminto & 50 & Demak \\
\hline 3. & Muhtar & 45 & Kendal \\
\hline 4. & Sukarjo & 51 & Kendal \\
\hline 5. & Zazid & 46 & Semarang \\
\hline 6. & Imam Suyuti & 45 & Semarang \\
\hline
\end{tabular}

The reason of choosing them as informants is because they are native community of each area, have shared knowledge regarding the local values, know much information of the attitude of the members of the community, and can give clear explanation regarding the local condition. Data are spoken texts produced by the informants during the interview. The researcher used a narrative method to gather the data, meaning that in interview the researchers use elicitation technique, in order to ask informants to produce narrative. To analyze the data, a critical discourse analysis approach [10] combined with the theory of cultural values [11] is used.

\section{Taboos, beliefs, and norms in the fisheries community in North Coast of Central java}

A group of people living together constructs a community controlled by certain regularities. Each member of a community has experience relating to the way they respond to the others. The knowledge, then, is shared socially and becomes 'properties of social agents' to organize their actions, to regulate their way of being, and to construct social relations [9]. Taboos, beliefs, and norms are a means of social organization functioning to control social individues [11].

The fishery communities in North Coast of Central Java especially in Semarang, Kendal, and Pekalongan, have also believed certain taboos regulating their life as fishermen. Among them can be grouped into four categories.

\subsection{Taboos in discourse practice}

As mentioned by Fairclough (1995) [10], when practicing discourse, every member of a community simultaneously also practices other non-discoursal activities, such as practicing action and interaction, identifying social relations, and constructing individual or group identification. To do that, the text producers are controlled by contextual regulation in the form of context of situation. Articulating discourse of taboos is a result of discourse process. Among the fishery community in North Coast of Central Java, certain taboo discourse can be found as follows.

(1) Do not talk about spirits

(2) Say hello and get permission when entering sacred places
(3) Do not utter matahari 'sun', bulan 'moon', pengantin 'bride', and perceraian 'divorce'

(4) Do not utter the name of land animals, utter the substitution

(5) Do not say that bad thing will happen

(6) Do not excessively express the sadness, the happiness, hatred

(7) Do not utter swear words

The taboos controlling discourse practice of the communities imply that among the community there is general knowledge stored in the long term memory of the members of community [12]. Besides controlling the discourse, the knowledge implies certain values controlling the mind of the community. The taboos no (1) and (2) imply that the community has still believed that the supernatural world has power to control the real world. Talking about spirits is percieved as an act of disturbing the life of the ghosta. People also believe that ghosta stay in certain places, so there is forbiden territory for human beings. The taboos perceive that the fishery community is superstitious. The belief is strengthened by other taboos such as in (3) and (4). They believed that bad things will happen if they violate the taboos.

Even though do not directly relate the superstition, taboos no (5), (6), and (7), represent the superstitious value among the community. They believe there is power controlling their minds and their activity. Therefore, they have to believe that their discourse expressing their thinking is also controlled by supernatural power.

\subsection{Taboos in social practice}

Similar to discourse practice, other non-discourse practices in the fishery community in North Coast of Central Java are also controlled by local values in the form of taboos.

(1) Do not spit on the sacred places

(2) Do not catch fish in forbidden places

(3) Pregnant women are forbidden to consume certain fish such as cuttlefish, squids, shrimps, and certain fish that have fins on their heads, and sembilang fish.

(4) Do not keep fishing when there is ombak banyak (goose wave) and kilat tancep (tancep lightning)

Looking at the list of taboos, we may interpret that the daily activities of the fishery community are controlled by the believe of supernatural power. Sacred places meaning places where spirits reside are places that must be respected and not be damaged. Spitting makes the place dirty, so it is forbidden. The community believes that disturbing the places may make the spirits angry and then revenge human being through making disaster.

Taboo (2) controlling the practice of catching fish implies the belief that fish in certain area are those that guard the sacred places or those that are the incarnation of spirits. Catching the fish means disturbing the existence of the spirits, and therefore it can be interpreted as practice against the supernatural power. 
Superstition also controls pregnant women. Instead of using logical thinking, the fishery community believes there is analogous relationship between certain parts or habits of certain fish and certain aspects of pregnancy. Cuttlefish, squids, and shrimps swim backward. The community believe that consuming the seafood, pregnant women will face problem when giving birth because the baby moves backward as the sea animals do.

Taboo (4) implies that the community sees certain wave and lightning as symbols given by supernatural power, instead of natural sign. The taboo becomes common knowledge among the fishery community guiding their activity in the sea.

\subsection{Taboos Taboos}

In North Coast of Central Java, fishing activities of the community is also constrained by temporal aspects. Similar to the local wisdom of other places, the community is forbidden to do fishing on certain days. Based on the interview result, the temporal taboo for fishing can be explained as follows.

(1) They do not go fishing on Friday

(2) They do not go fishing on the day when their parents died (geblag)

(3) They do not launch a boat after painted on the day when their parents died (geblag)

Regarding temporal taboos as mentioned above, we may interpret that there is a mixed belief between religious aspect and superstitious aspect. Friday is a special day for moslems because Friday is sacred day. Moslems, especially men, must do congregational worship/prayer. However, it becomes social practice of taboo, meaning that if people try to do against to taboo, bad thing will happen to them. It means that the community exploits the religious rule to control the social practice of the community.

The temporal taboo also shows us that the community believes the day when their parents and their achestor died as a sacred day. They are forbidden to do important activities, and they are forbidden to make important decision. People believe that something bad or bad luck will happen if they are against the taboos. Such community shows the tendency of being the harmonious community [11].

\subsection{The attitude of the existing fishery community towards taboos}

Taboos have existed among the fishery community in North Coast of Central Java since long time ago. There is no information who established the taboos and when the taboos were created. They resulted from individual experiences and then became collective knowledge stored in the long term memory of the community's members. Taboos were inherited from generation to generation. Taboos contain prohibitions or orders to do certain practices. If taboos are violated, it is believed that bad luck will happen to the one who violates them. The threat makes people try not to violate them.
Based on the result of the interview, the existing fishery community realizes that taboos are merely knowledge they got from their parents or from the old generation through story they constructed. The use of the word katanya 'he/she said' or 'people said' in talking about the taboos proved that they did not fully commit the truth of what they said. However, the personal experiences of some members of the community regarding the bad lucks are connected with the existence of taboos.

The result of the personal interview with Nasikin showed that the community shared contradictive knowledge regarding the belief. On one hand, they believe that there is supernatural power controlling the sea. Every accident or bad event happening to the fisheries community is under control of the supernatural creature. On the other hand, they realize that they have religion and must believe that bad or good events happening to people are under control of God. The dual beliefs were represented in their social practice when there was a fisherman getting sick soon after he was angry in the sea. Taking the sick person to doctor is representation of their belief in God. However, when they thought that the doctor was not able to cure him, their belief of supernatural power dominated their reasoning. Therefore, instead of keeping to consult the doctor, the family took him to the shaman. They believed what the shaman said that the sick man was victimized by the supernatural creature controlling the sea.

Being sick is a natural happening. Every living creature has possibility of being sick. Modern society has knowledge that there are various diseases that have not been healed. When someone keeps illness even though he/she has got treatment, the modern society may think that he/she has not been cured appropriately or that there has not been found the cure. However, the fishery community relates the event of violating taboos with the condition of being sick. It is believed that the sick condition is as consequence of violating the taboos. Therefore, instead of keeping trying to find the appropriate modern healing, they believe that spirits are disturbing him/her, so they bring him/her to shaman.

Associative relation between violating taboos and bad luck that happened several times resulted in collective knowledge about superstition. People became superstitious. They can not prove the truth of their perception. However, to avoid the badluck or possible disaster, the community has the attitude to obey the collective control.

On one hand, their increased understanding and faith, especially about Islamic religion has shifted their understanding of the prohibited myth. Holding a ceremony to honor the spirit that they call larung is more interpreted as customs rather than believing in the power of the spirit. On the other hand, all requirements in holding the ceremony such as offering the buffalo head to the ruler of the sea still have been fulfilled. They are fear of consequences of violating the tradition. The ambiguous attitude resulted in the acculturated tradition between believing the power of spirits and practicing 
religious rule. They conduct every step of the offering ceremony based on the existing tradition but practice Islam religion in praying.

\section{The influence of taboos, beliefs, and norms on balancing marine ecosystem}

Of the taboos constructed by the fishery community, there are few which relate to the marine ecosystem. The prohibition of catching fish in certain places and in certain days may inhibit attempt to exploit the fish population. However, it is not significant. Instead, the balancing marine population is maintained through the traditional fishing gear and boat. The community catch fish for fulfilling their daily needs and for being sold in traditional market. They also have belief that fish in the sea will never run out.

So far, there is no taboo related to keeping the cleanliness of the sea. The prohibition of spitting is adjusted to land site because some sacred places are on the land site. When fishing, they easily throw away plastic or other marine litter. The interview resulted that the community do not have consciousness of keeping the sea clean.

\section{The relevance of taboos, beliefs, and norms in the fisheries community to face industrial era 4.0}

The taboos identified in the fishery community in North Coast of Central Java, based on the interview, function as a device to control the social practice and mind of the community members. Imposing such values continuously from a generation to the next generation has resulted in the common perception among the member of the community. The shared knowledge is, then, used to solve the social problems in their daily lives. This makes the members of community become superstitious people and avoid logical thinking.

The superstitious viewpoint, however, may make the community find the difficulty to face problems in industrial era 4.0. People in the era must have competence in handling problems fast and appropriately. Having thought that getting accident when fishing has relationship with violating the taboos result people who are less innovative. It causes people to surrender to fate without trying to find the real causes. Instead, they must think that accident may happen because they are incautious, there is bad weather, or their boat is not safe. When the fishery community can not catch the large quantities of fish and then they think that it is because they have not given offerings to the spirits, it cause them passive people. They are reluctant to think that lack of fish may be caused by the damage of the ecosystem. When they think that getting illness is caused by curse of the spirit, they tend to believe in shaman, instead of seeing the doctor.

\section{Conclusion}

Taboos occur in almost every community. They have been constructed based on the personal experience of individual member, and become knowledge shared by the members. In the North Coast of Central Java, the fishery community has trusted some taboos. The result of the study can be concluded that some taboos that control the fishery community are similar to the ones controlling the general Javanese community, such as getting permission when entering the sacred places, avoiding doing important acts on geblag, and not saying something bad will happen. They are typical values of community who still believe in spirit's force. Some other taboos relate to the fishery's life, such as prohibition of consuming certain fish, of uttering certain entities, and of catching in forbidden places. The taboos do not directly relate to the effort of balancing marine ecosystem. However, so many prohibitions when going fishing may control marine exploitation. The negative impact of the existence of taboos among the fishery community in the North Coast of Central Java is that believing in the taboos may inhibit the community to think realistically. They surrender the fate, instead of facing and finding the problems or difficulties they have.

\section{References}

1. K.M. Tengö, F. Johansson, Rakotondrasoa, J. Lundberg, J-A. Andriamaherilala, J-A. Rakotoarisoa, T. Elmqvist, A. M. 36, 638-691 (2007).

2. J. P. G. Jones, M. M. Andriamarovololona, N. Hockley, C.B. 22, 976-986 (2008)

3. Y. N.Baidu, J.S.R.N.C. 2, 309-326 (2008)

4. D. J.Beaulaton, J.S.R.N.C. 2, 351-372 (2008)

5. T. L. Saj, C. Mather, P. Sicotte, S.S.I. 45, 285-310 (2006)

6. V. Valeri, The Forest of taboos : Mortality, hunting, and identity among the Huaulu of the Moluccas (2000)

7. M. Putri, Nurpratiwi, J.P.W.K. 27, 49-67 (2016)

8. D. H. Nugraha, P. K. Widyapura, J.S.E.P.U. 9, 1-7 (2017)

9. S. D. Wulanningrum, T. B. Jayanti, J.P.K. 4, 21-28 (2016)

10. N. Fairclough, Critical discourse analysis (1995)

11. S. H.Schwartz. C.J. 5,2-3 (2006)

12.T. A. van. Dijk, Principles of critical discourse analysis

(1993) 